\title{
The net present value of human lives lost due to coronavirus disease (COVID-19) in the Islamic Republic of Iran
}

Joses M. Kirigia ( $\square$ muthurijoses68@gmail.com )

ASDRC https://orcid.org/0000-0002-2317-4666

Rose Nabi Deborah Karimi Muthuri

University of Pretoria

Newton Gitonga Muthuri

United States International University, Nairobi

\section{Research note}

Keywords: Coronavirus disease, net present value of human lives, non-health gross domestic product

Posted Date: May 24th, 2020

DOI: https://doi.org/10.21203/rs.3.rs-24711/v1

License: (c) (1) This work is licensed under a Creative Commons Attribution 4.0 International License.

Read Full License 


\title{
The net present value of human lives lost due to coronavirus disease (COVID-19) in the Islamic Republic of Iran
}

\author{
Joses M. Kirigia ${ }^{1^{*}}$ \{Email: muthurijoses68@gmail.com) \\ Rose Nabi Deborah Karimi Muthuri² \{email: u19391189@tuks.co.za\} \\ Newton Gitonga Muthuri³ ${ }^{\text {\{Email: nmuthuri@usiu.ac.ke\} }}$ \\ ${ }^{1}$ African Sustainable Development Research Consortium (ASDRC), Nairobi, \\ Kenya \\ ${ }^{2}$ Faculty of Health Sciences, University of Pretoria, Hatfield, Pretoria 0002, \\ South Africa \\ ${ }^{3}$ Chandaria School of Business, United States International University - Africa, \\ P.O. 14634-00800, Nairobi, Kenya
}

*Corresponding author: Professor Joses M. Kirigia, ASDRC, P.O. Box 699400100 GPO, Nairobi, Kenya. Email: muthurijoses68@gmail.com. Tel: +254720664167. 


\section{Abstract}

Objective: As of 11 April 2020, there were 68,192 confirmed cases, including 4,232 deaths. This study aimed to estimate the net present value of human lives lost due to COVID-19 in Iran as of 11 April 2020.

Results: The 4,232 human lives lost had a total net present value of Int $\$ 436,275,007$. The average net present value per human life was Int $\$ 103,090$. Re-estimation of the economic model with $5 \%$ and $10 \%$ discount rates resulted in a reduction in the expected total net present value by Int $\$ 64,881,144$ (14.9\%) and Int\$168,066,782 (38.5\%), respectively. Additional re-calculation of the economic model using the highest life expectancy in the world (i.e., that of the Japanese Females) increased the total net present value of human lives lost by $114 \%$.

Keywords: Coronavirus disease; net present value of human lives; non-health gross domestic product 


\section{Introduction}

The Islamic Republic of Iran, an upper-middle-income economy, is one of the 21 Member States of the WHO Eastern Mediterranean Region (EMR) [1]. The country has a population of 84.1 million persons, a gross domestic product (GDP) of Int $\$ 1,500.5$ billion, and a per capita GDP (PCGDP) of Int 17,832 [2].

As of 11 April 2020, globally, there were 1,610,909 confirmed cases of COVID-19; and 99,690 deaths. The EMR had 92,226 confirmed COVID-19 cases and 4,771 deaths. Iran borne 68,192 (74.7\%) of confirmed cases and 4,232 (89.2\%) deaths in the EMR [3].

Why has Iran borne a disproportionate share of COVID-19 cases and deaths? It could be due to gaps in the Universal Health Coverage (UHC), International Health Regulations (IHR), and coverage of water and sanitation. UHC, which means Iranians receive the essential health services they need without suffering financial hardship, can be viewed as a proxy indicator of the strength and resilience of the underlying national health system [4]. Iran has a UHC service coverage index of $65 \%$, implying a $35 \%$ gap in the coverage of reproductive, maternal, new-born and child health, infectious diseases (such as COVID-19); non-communicable diseases; and service capacity and access. About $3.8 \%$ of the population spent above $25 \%$ of their income on health care.

The IHR capacities are a proxy of the vibrancy of the national disease surveillance system [5]. In 2018 IHR capacities of chemical events, laboratory, health service provision, national health emergency framework, and legislation and financing had a rating of $100 \%$ [6]. The IHR coordination and national IHR focal point functions, food safety, surveillance, human resources, risk communication, and radiation emergencies had a rating of $80 \%$, implying a $20 \%$ gap. While the points of entry, the zoonotic events, and the human-animal interface IHR capacities had a rating of $60 \%$, implying a gap of $40 \%$. The average of 13 IHR core capacity scores was $85 \%$, implying an overall gap of $15 \%$ [7].

The coverage of basic water and sanitation services are proxy indicators for the performance of systems that tackle social determinants of health. In $2017,88 \%$ of the Iranian population was using at least basic sanitation services, implying that $12 \%$ were not [8]. In the same year, $92 \%$ of the population were using safely managed drinking-water services, implying that $8 \%$ were not [9].

Iran's current health expenditure per capita of US\$475.5 in 2017 [10], although within the range of US\$ 297 (minimum) to US\$984 (maximum), it was lower than the upper-middle-income countries recommended population-weighted mean of US\$536 per person [11].

Thus, there is a need for evidence on the net present value of human lives for use in advocating for increased investments in expanding coverage of essential health services, water and sanitation, and IHR capacities. To the best of our knowledge, no study has estimated the net present value of human lives lost from COVID-19 in Iran. This study aimed to estimate the net present value of human lives lost due to COVID-19 in Iran as of 11 April 2020.

\section{Main text}

\section{Methods}

\section{Estimating the net present value of human lives lost}

The current study used the human capital approach (HCA) pioneered Petty [13] in the $16^{\text {th }}$ Century and further refined by Farr [14] in the $18^{\text {th }}$ Century. Fein [15], Mushkin and Collings [16], Landefeld 
and Seskin [17], Linnerooth [18], and Weisbrod [19] provides the theoretical foundations for applications of HCA to value human life.

According to Weisbrod [19], "..the value of a person to others is measured by any excess of his contribution to production over what he consumes from production...The present value of a man at any given age may be defined operationally as his discounted expected future earnings stream (net of his consumption)" (pp.426-427). Also, the WHO guide to identifying the economic consequences of disease advises that the expenditures on health should be removed GDP in the valuation of a human life lost [20]. This study followed the counsel of Weisbrod [19] and WHO [20] to estimate the net present value of human lives lost (NPVHL) due to COVID-19 in Iran.

The formulas developed and applied in a recent study on the fiscal value of human lives lost due to COVID-19 deaths in China [21] were adapted and used to estimate the total NPVHL from COVID-19 in Iran (NPVHL $\left.L_{I R A N}\right)$. The only difference was that while the China study assessed value of human lives lost for three age groups (24-49 years, 50-64 years, and 65 years and above), the Iran study appraised the NPVHLL for nine age groups, including the 0-9-year-old $\left(N P V H L_{0-9}\right)$, 10-19-year-old $\left(N P V H L_{10-19}\right), 20-29$-year-old $\left(N P V H L_{20-29}\right), 30$-39-year-old $\left(N P V H L_{30-39}\right), 40-49$-year-old $\left(N P V H L_{40-49}\right)$, 50-59-year-old $\left(N P V H L_{50-59}\right), 60-69$-year old $\left(N P V H L_{60-69}\right)$, 70-79-year-old $\left(N P V H L_{70-79}\right)$, and 80-year-old and above $\left(N P V H L_{\geq 80}\right)$. The $N P V H L_{I R A N}$ due to COVID-19 in Iran was derived using the following equations [21]:

$$
\begin{aligned}
& N P V H L_{I R A N}=\left(\begin{array}{l}
N P V H L_{0-9}+N P V H L_{10-19}+N P V H L_{20-29}+N P V H L_{30-39}+N P V H L_{40-49} \\
+N P V H L_{50-59}+N P V H L_{60-69}+N P V H L_{70-79}+N P V H L_{\geq 80}
\end{array}\right) .(1) \\
& N P V H L_{j}=\sum_{t=1}^{t=n}\left\{\left[1 /(1+r)^{t}\right] \times\left[N G D P P C_{\text {Int } \$}\right] \times[C O V D]\right\}= \\
& \left.\left\{1 /(1+r)^{1}\right] \times\left[N G D P P C_{I n t \$}\right] \times\left[C O V D_{j}\right]\right\}+ \\
& \left.\left\{1 /(1+r)^{2}\right] \times\left[N G D P P C_{I n t \$}\right] \times\left[C O V D_{j}\right]\right\}+\ldots+ \\
& \left.\left\{1 /(1+r)^{n}\right] \times\left[N G D P P C_{I n t \$}\right] \times\left[C O V D_{j}\right]\right\}
\end{aligned}
$$

Where: $1 /(1+r)^{t}$ is the discount factor; $r$ is the discount rate; $\sum_{t=1}^{t=n}$ is the total from year $t=1$ to $t=n ; t=1$ is the first year of life lost to COVID-19 and $n$ is the last year of life of lost to COVID-19 within an age group; NGDPPC $C_{I n t \$}$ is net GDP per person in International Dollars (Int\$), obtained by subtracting current health expenditure per person (CHEPP) from per capita GDP (PCGDP); $C O V D_{j}$ is the number of human lives lost from COVID-19 in the $\mathrm{j}^{\text {th }}$ age group. The base year was 2020 . The detailed model and illustration of how to estimate the equations can be found in Kirigia and Muthuri [21].

\section{Data and data sources}

The data and sources are contained in Table 1.

\begin{tabular}{|l|l|l|}
\hline \multicolumn{2}{|l|}{ Table 1: Data and data sources } \\
\hline Variable & Data value & Source \\
\hline
\end{tabular}




\begin{tabular}{|c|c|c|}
\hline $\begin{array}{l}\text { Number of COVID-19 deaths } \\
\text { for Iran as of } 11 \text { April } 2020 .\end{array}$ & 4,232 & $\begin{array}{l}\text { WHO COVID-19 } \\
\text { report } 82 \text { [3] }\end{array}$ \\
\hline $\begin{array}{l}\text { Distribution of COVID-19 } \\
\text { deaths by age group }\end{array}$ & $\begin{array}{l}0-9 \text { years }=0 ; 10-19 \text { years }= \\
0.0009775 ; \quad 20-29 \text { years }= \\
0.0068426 ; \quad 30-39 \text { years = } \\
0.0175953 ; \quad 40-49 \text { years }= \\
0.0371457 ; \quad 50-59 \text { years = } \\
0.1270772 ; \quad 60-69 \text { years = } \\
0.3020528 ; \quad 70-79 \text { years = } \\
0.3049853 ; \text { and } 80 \text { years and } \\
\text { above }=0.2033236\end{array}$ & Verity et al. [12] \\
\hline $\begin{array}{l}\text { Iran's life expectancy at birth in } \\
\text { years }\end{array}$ & 75.7 years & $\begin{array}{l}\text { WHO World Health Statistics } \\
2019 \text { [7] }\end{array}$ \\
\hline $\begin{array}{l}\text { Global average life expectancy } \\
\text { in years }\end{array}$ & 72 years & $\begin{array}{l}\text { WHO World Health Statistics } \\
2019 \text { [7] }\end{array}$ \\
\hline $\begin{array}{l}\text { World's highest life expectancy } \\
\text { in years }\end{array}$ & 87.1 years & $\begin{array}{l}\text { WHO World Health Statistics } \\
2019 \text { [7] }\end{array}$ \\
\hline Iran's per capita GDP (PCGDP) & Int\$17,832 & $\begin{array}{l}\text { IMF World Economic Outlook } \\
\text { database [2] }\end{array}$ \\
\hline $\begin{array}{l}\text { Current health expenditure per } \\
\text { person in Iran (CHEPP) }\end{array}$ & Int\$1,748 & $\begin{array}{l}\text { WHO Global Health } \\
\text { Expenditure Database [10] }\end{array}$ \\
\hline Net GDP per capita (NGDPPC) & $\begin{array}{l}\text { NHGDPPC= PCGDP }- \text { NHGDPPC } \\
=\operatorname{lnt} \$ 17,832-\operatorname{lnt} \$ 1,748=\ln \$ \\
16,084\end{array}$ & Authors calculation. \\
\hline
\end{tabular}

\section{Results}

Table 2 shows the distribution of the net present value of human lives lost from COVID-19 by age group.

\begin{tabular}{|l|l|l|l|}
\hline \multicolumn{3}{|l|}{$\begin{array}{l}\text { Table 2: Net present value of human lives lost due to COVID-19 in Iran (in 2020 Int\$) - } \\
\text { at three discount rates }\end{array}$} \\
\hline Age group in years & $\begin{array}{l}\text { Net present value of } \\
\text { human lives lost at } \\
\text { 3\% discount rate } \\
\text { (Int\$) }\end{array}$ & $\begin{array}{l}\text { Net present } \\
\text { value of } \\
\text { human lives } \\
\text { lost at 5\% } \\
\text { discount rate } \\
\text { (Int\$) }\end{array}$ & $\begin{array}{l}\text { Net present value of } \\
\text { human lives lost at } \\
\text { 10\% discount rate } \\
\text { (Int\$) }\end{array}$ \\
\hline $0-9$ & 0 & 0 & 0 \\
\hline $10-19$ & $1,852,417$ & $1,262,893$ & $6,63,385$ \\
\hline $20-29$ & $12,087,042$ & $8,541,561$ & $11,736,117$ \\
\hline $30-39$ & $28,040,292$ & $20,712,918$ & $23,966,842$ \\
\hline $40-49$ & $50,569,305$ & $39,425,035$ & $74,809,713$ \\
\hline $50-59$ & $133,337,298$ & $110,900,758$ & \\
\hline
\end{tabular}




\begin{tabular}{|l|r|r|r|}
\hline $60-69$ & $190,233,715$ & $170,779,664$ & $133,538,288$ \\
\hline $70-79$ & $20,154,938$ & $19,771,034$ & $18,872,351$ \\
\hline$>=80$ & 0 & 0 & 0 \\
\hline Total & $436,275,007$ & $371,393,863$ & $268,208,225$ \\
\hline $\begin{array}{l}\text { Average net present } \\
\text { value per human life } \\
\text { lost }\end{array}$ & 103,090 & & 63,376 \\
\hline
\end{tabular}

The 4,232 human lives lost had a total net present value of Int\$ $436,275,007$ (0.03\% of Iran's total GDP), i.e., assuming a discount rate of $3 \%$ and Iran's average life expectancy at birth of 75.7 years. Of which, $0.4 \%$ was borne by the $10-19$-year-olds'; $2.8 \%$ by 20 -29-year-olds; $6.4 \%$ by 30 -39-year-olds; $11.6 \%$ by $40-49$-year-olds; $30.6 \%$ by $50-59$-year-olds; $43.6 \%$ by $60-69$-year-olds; and $4.6 \%$ by $70-79$ year-olds.

The average net present value per human life was Int $\$ 103,090$. The average net present value per death decreased with an increase in age. For example, the net present value per death among 10-19year-olds was Int $\$ 447,784$ compared to Int $\$ 15,616$ per death among $70-79$-year-olds.

The economic model was re-estimated with $5 \%$ and $10 \%$ discount rates to gauge the impact on the total net present value of human lives lost to COVID-19. Use of those discount rates resulted in a reduction in the expected total net present value by Int\$ 64,881,144 (14.9\%) and Int\$168,066,782 (38.5\%), respectively. The corresponding decreases in average net present value per human life lost due to COVID-19 were Int\$15,331 and Int\$39,713.

Table 3 compares the net present value of human lives lost from COVID-19 in Iran, assuming Iran's, global, and world's highest life expectancies.

Table 3: A comparison of net present value of human lives lost from COVID-19 in Iran: assuming Iran's, global and world's highest life expectancies (in 2020 Int\$ or PPP)

\begin{tabular}{|l|l|l|l|}
\hline Age group in years & $\begin{array}{l}\text { Net present value of } \\
\text { human lives lost at } \\
\text { 3\% discount rate } \\
\text { and assuming the } \\
\text { Iran's average life } \\
\text { expectancy of 75.7 } \\
\text { years (Int\$) }\end{array}$ & $\begin{array}{l}\text { Net present } \\
\text { value of } \\
\text { human lives } \\
\text { lost at 3\% } \\
\text { discount rate } \\
\text { and assuming } \\
\text { the global } \\
\text { average life } \\
\text { expectancy of } \\
\mathbf{7 2} \text { years (Int\$) }\end{array}$ & $\begin{array}{l}\text { Net present value of } \\
\text { human lives lost at } \\
\text { 3\% discount rate } \\
\text { and assuming } \\
\text { world's highest life } \\
\text { expectancy of 87.1 } \\
\text { years (Int\$) }\end{array}$ \\
\hline $0-9$ & 0 & & 0 \\
\hline $10-19$ & $1,852,417$ & $1,830,159$ & $1,961,559$ \\
\hline $20-29$ & $12,087,042$ & $11,768,220$ & $13,113,784$ \\
\hline $30-39$ & $28,040,292$ & $26,938,511$ & $31,588,493$ \\
\hline $40-49$ & $50,569,305$ & $47,443,379$ & $60,636,107$ \\
\hline $50-59$ & $133,337,298$ & $118,965,514$ & $179,620,515$ \\
\hline $60-69$ & $190,233,715$ & $144,324,692$ & $338,080,167$ \\
\hline
\end{tabular}




\begin{tabular}{|l|r|l|l|}
\cline { 3 - 4 } $70-79$ & $20,154,938$ & & $-220,777,268$ \\
\hline$>=80$ & 0 & - & $86,225,396$ \\
\hline Total & $436,275,007$ & $351,270,475$ & $932,003,289$ \\
\hline $\begin{array}{l}\text { Average net present } \\
\text { value per human life } \\
\text { lost }\end{array}$ & 103,090 & & 220,228 \\
& & & \\
\hline
\end{tabular}

Re-appraisal of the economic model, assuming the lower global average life expectancy at birth of 72 years, resulted in a total net present value of Int $\$ 351,270,475$ and an average net present value of Int83,003 per death. Thus, the use of a lower average life expectancy reduced the total net present value by Int\$83,003 (19\%).

Re-analysis of the economic model using the highest life expectancy in the world (i.e., that of the Japanese Females) increased the total net present value to Int\$932,003,289 and the average net present value of Int $\$ 220,228$. Therefore, the use of the highest average life expectancy in the world increased the total net present value by Int $495,728,282$ (114\%).

\title{
Limitations
}

Our study had some limitations. First, according to the WHO World Health Statistics Report 2019, the completeness of cause-of-death data was $65 \%$ in 2017 [7]. The cause-of-death for about $35 \%$ of deaths is not recorded. Therefore, the number of notified COVID-19 cases and deaths are likely to be an underestimate. Should that be the case, the total net present value of human lives lost reported in this paper would also be an underestimate.

Second, our study omits the COVID-19 health system costs related to prevention (water, soap, sanitizers, personal protective equipment), testing (diagnosis), case tracing, quarantine, and hospitalization of severe cases, and post-mortem. We also did not take into account funeral-related costs, including the purchase of caskets, hiring of a hearse, transport of the bodies (and family and friends), funeral ceremonies, and time of family and friends preparing and attending the funerals [21].

Third, given the limited scope, this study did not take into account the macroeconomic impact of COVID-19 pandemic on agriculture, education, financial services (e.g., banking and stock exchange), hydrocarbon (oil and gas), international trade and commerce, tourism and travel, and manufacturing sectors [23].

Finally, when strictly applied, the human capital approach employed in the current study would value the contributions of housewives, the elderly, the handicapped (physically and mentally), and children at zero [23]. To avoid human rights and ethical issues, we valued all the years of life lost, irrespective of age, gender, and economic status, using the same numeraire, i.e., net GDP per capita.

\author{
Abbreviations \\ CHEPP: current health expenditure per person \\ COVID-19: Coronavirus disease
}


COVD $_{\mathrm{j}}$ : Number of COVID-19 deaths in $\mathrm{j}^{\text {th }}$ age group

DSS: Disease surveillance system

EMR: Eastern Mediterranean Region

GDP: Gross domestic product

HCA: Human capital approach

IHR: International health regulations

IMF: International Monetary Fund

Int\$: International Dollars or Purchasing Power Parity (PPP)

NVHL: Net present value of human lives lost

NPVHLIRAN= Net present value of human lives lost in Iran due to COVID-19 deaths

NPVHLo-9: Net present value of potential years of life lost among those aged 0-9 years

$\mathrm{NPVHL}_{10-19}$ : Net present value of potential years of life lost among those aged 10-19 years

NPVHL 20-29: Net present value of potential years of life lost among those aged 20-29 years

$\mathrm{NPVHL}_{30-39}$ : Net present value of potential years of life lost among those aged 30-39 years

NPVHL $40-49$ : Net present value of potential years of life lost among those aged $40-49$ years

$\mathrm{NPVHL}_{50-59}$ : Net present value of potential years of life lost among those aged 50-59 years

NPVHL60-69: Net present value of potential years of life lost among those aged 60-69 years

$\mathrm{MVHL}_{70-79}$ : Net present value of potential years of life lost among those aged 70-79 years

$\mathrm{NPVHL}=80$ : Net present value of potential years of life lost among those aged 80 years and above

NGDPPC Intș: Non-health GDP per person in purchasing power parity

NHS: National health system

PCGDP: Per capita GDP

r: Discount rate

SDH: Social determinants of health

UHC: Universal health coverage

US\$: United States Dollar

WHO: World Health Organization

\section{Declarations}

Ethics approval and consent to participate 
Not applicable. No ethical clearance was required because the study relied completely on analysis of secondary data available in public sources.

\section{Consent for publication}

Not applicable.

\section{Availability of data and materials}

All data generated or analysed during this study are included in this published article.

\section{Competing interests}

The authors declare that they have no competing interests.

\section{Funding}

None.

\section{Authors' Contributions}

JMK, RDKM and NGM designed the study; extracted the data from various databases and reports; designed the economic model on Excel software; reviewed literature; and drafted the manuscript. Both authors approved the final version of the paper.

\section{Acknowledgements}

Jehovah Jireh met all our needs in all stages of the study. This paper is dedicated to COVID-19 patients and their families, human resources for health, national health development leaders, private sector and international health development partners waging a spirited war against COVID-19. The views expressed in this paper are solely those of the authors and should not be attributed to institutions they are affiliated to. 


\section{References}

1. World Health Organization. World health statistics 2018: monitoring health for the SDGs, sustainable development goals. Geneva: World Health Organization; 2018.

2. International Monetary Fund (IMF). World Economic Outlook Database. Washington, D.C.: IMF; 2019. https://www.imf.org/external/pubs/ft/weo/2019/02/weodata/index.aspx. Accessed 10 April 2020.

3.World Health Organization (WHO). Coronavirus disease 2019 (COVID-19) Situation Report - 82. 11 April 2020. Geneva: WHO; 2020. https://www.who.int/emergencies/diseases/novel-coronavirus2019/situation-reports. Accessed 12 April 2020.

4. WHO. Global Health Observatory. UHC country data profile. Geneva: WHO; 2020. https://apps.who.int/gho/portal/uhc-country.jsp. Accessed 10 April 2020.

5. WHO. IHR core capacity monitoring framework: checklist and indicators for monitoring progress in the development of IHR core capacities in states parties. Document WHO/HSE/GCR/2013.2. Geneva: WHO; 2013.

6. WHO. Global Health Observatory data repository. International Health Regulations (2005) monitoring framework, SPAR. Geneva: WHO; 2020. https://apps.who.int/gho/data/node.main.IHRSPARALL?lang=en. Accessed 10 April 2020.

7. World health statistics overview 2019: monitoring health for the SDGs, sustainable development goals. Geneva: World Health Organization; 2019

8. WHO. Global Health Observatory data repository. Basic and safely managed sanitation services. Geneva: WHO; 2020. https://apps.who.int/gho/data/node.main.WSHSANITATION?lang=en Accessed 11 April 2020.

9. WHO. Global Health Observatory data repository. Basic and safely managed drinking water services. Geneva: WHO; 2020. https://apps.who.int/gho/data/node.main.WSHWATER?lang=en. Accessed 11 April 2020.

10. WHO. Global health observatory. Current health expenditure (CHE). Geneva: WHO; 2020. https://www.who.int/data/gho/data/themes/topics/indicator-groups/indicator-groupdetails/GHO/current-health-expenditure-(che). Accessed 12 April 2020.

11. Karin Stenberg, Odd Hanssen, Tessa Tan-Torres Edejer, Melanie Bertram, Callum Brindley, Andreia Meshreky, James E Rosen, John Stover, Paul Verboom, Rachel Sanders, Agnès Soucat. Financing transformative health systems towards achievement of the health Sustainable Development Goals: a model for projected resource needs in 67 low-income and middle-income countries. Lancet Glob Health 2017; 5: e875-87

12. Verity R, Okell LC, Dorigatti I, Winskill P, Whittaker C, Imai N, Cuomo-Dannenburg G, Thompson H, Walker PGT, Fu H, Dighe A, Griffin JT, Baguelin M, Bhatia S, Boonyasiri A, Cori A, Cucunubá Z, FitzJohn R, Gaythorpe K, Green W, Hamlet A, Hinsley W, Laydon D, Nedjati-Gilani G, Riley S, van Elsland S, Volz E, Wang H, Wang Y, Xi X, Donnelly CA, Ghani AC, Ferguson NM. Estimates of the severity of coronavirus disease 2019: a model-based analysis. Lancet Infect Dis. 2020. https://doi.org/10.1016/ S1473-3099(20)30243-7. 
13. Petty W. Political Arithmetick, or a Discourse: Concerning, the Extent and Value of Lands, People, Buildings; Husbandry, Manufacture, Commerce, Fishery, Artizans, Seamen, Soldiers; Publick Revenues, Interest, Taxes, Superlucration, Registries, Banks; Robert Caluel: London, UK, 1699.

14. Farr W. The Income and Property Tax. J. R. Stat. Soc. 1853; 16:1-44.

15. Fein R. Economics of Mental Illness. New York: Basic Books; 1958.

16. Mushkin SJ, Collings FA. Economic costs of disease and injury. Public Health Rep. 1959; 74:795809.

17. Landefeld JS, Seskin EP. The economic value of life: Linking theory to practice. Am. J. Public Health. 1982; 72:555-566.

18. Linnerooth, J. The value of human life: A review of the models. Econ. Inq. 1979; 17:52-74.

19. Weisbrod BA. The Valuation of Human Capital. The Journal of Political Economy. 1961; 69(5):425436.

20. WHO. WHO guide to identifying the economic consequences of disease and injury. Geneva: WHO; 2009.

21. Kirigia JM, Muthuri RNDK. The fiscal value of human lives lost from coronavirus disease (COVID19) in China. BMC Res Notes. 2020; 13:198. https://doi.org/10.1186/s13104-020-05044-y

22. Kirigia JM, Muthuri RDK, Nabyonga-Orem J, Kirigia DW: Counting the cost of child mortality in the World Health Organization African region. BMC Public Health 2015; 15:1103.

https://doi.org/10.1186/s12889-015-2465-z.

23. Arezki R, Nguyen H. Novel coronavirus hurts the Middle East and North Africa through many channels. In: Baldwin R, Mauro BW (Editors). Economics in the Time of COVID-19. Chapter 4, pp.5358 Geneva: Centre for Economic Policy Research (CEPR) Press; 2020. 